\title{
Comic Strip as Indonesian Tribes Diversity Lesson for Grade IV Students
}

\author{
Moh. Fathurrahman* \\ Elementary School Teacher Education Department \\ Universitas Negeri Semarang \\ Semarang, Indonesia \\ fathurrahman@mail.unnes.ac.id \\ Deni Setiawan \\ Elementary School Teacher Education Department \\ Universitas Negeri Semarang \\ Semarang, Indonesia \\ deni.setiawan@mail.unnes.ac.id
}

\author{
S Sukarjo \\ Elementary School Teacher Education Department \\ Universitas Negeri Semarang \\ Semarang, Indonesia \\ sukarjopgsd@mail.unnes.ac.id \\ Rizka Nurul Izmi \\ Elementary School Teacher Education Department \\ Universitas Negeri Semarang \\ Semarang, Indonesia \\ rizkanurulizmi@gmail.com
}

\begin{abstract}
This research is motivated by the low outcomes of students in learning social studies subjects due to the limitations of learning media both supply and use. Therefore, researchers conduct development research intending to develop and produce media illustrated story products and find out their feasibility and effectiveness. The problem above is solved by the Research and Development (R\&D) method according to Sugiyono. The development of media illustrated story gained $97.5 \%$ material expert evaluation with very decent criteria and $85.3 \%$ media expert with very decent criteria. Media illustrated story influences student learning outcomes as evidenced by an increase in the average pretest result of 54.6 and an average posttest of 76. Media illustrated story is effectively used in social studies subjects on social, economic, cultural, ethnic, and religious diversity in Indonesia is shown from the calculation of $\mathrm{N}$-gain of 0.4705 with moderate criteria. Based on these results it can be concluded that the media illustrated story is feasible and effectively used in social studies subjects on social, economic, cultural, ethnic, and religious diversity in Indonesia.
\end{abstract}

Keywords- Media Learning, illustrated story, social sciences subjects

\section{INTRODUCTION}

According to Susanto social science is the subject that studies social disciplines as well as the human's basic activities in primary and secondary degrees covering various life aspects either social, economics, history, culture, or politics. Susanto also explained, Social Science learning mainly aims to develop the students' potential to be aware of the social issues, to have positive thinking about all the emerging imbalance, and to be good at coping with any problems coming to both himself and his society [1].

The study is underlined by poor Social Science learning outcomes of grade IV students in SDN 1 Munggu. This is in line with the data that I collected from the interviews with the grade IV teacher and students in SDN 1 Munggu that shows that the students still find understanding the lesson material difficult because of the insufficient media provided by the school. The students were uninterested because the teacher did not apply the learning media at best. In addition, the teacher still applied Direct Instruction where the learning was teacher-centered. The teacher also found it difficult to create an alternative tool that can support the Social Science learning activities due to the elaborate lesson materials. The learning media at schools for Social Science learning are available only for certain lesson materials such as printed pictures, globes, and atlas.

Referring to the study conducted by Adzka (2019) the development of the learning media that can improve the students' comprehension is necessary [2]. As Suryani et.al. said, learning media is defined as everything that is used to deliver messages that will stimulate the students' thinking, feeling, enthusiasm, and will so it encourages the purposeful, intentional, controlled learning process. Defines learning media as physical aid kits that are used as the media by the teacher to deliver the lesson materials to the students to boost the learning quality [3].

Referring to the study conducted by Masruro (2018), pictures will boost the kids' imagination and a story will both make the student think critically and do the things told in the story [4]. Similarly, the study conducted by Arash (2018) shows that picture books can provide children with free space for imagination and creation, allowing them to create multidimensional meaning of the text through the reading process [5].

Based on the background and the relevant studies above, the study will use the Research and Development method in developing social science learning media. In general, the problems stated in the study are how to develop the design, the feasibility, and the applicability of small group testing on comic strips as the learning media for grade IV students in SDN 1 Munggu. The study aims to develop, to test the feasibility and the effectiveness of comic strips for the learning of social, economic, cultural, ethnic, and religious diversity in Indonesia in Social Science subject for grade IV students of SDN 1 Munggu.

\section{METHODS}

Research design is the procedure or guidelines I used as the reference in the study. I applied research and development as the research method. Sugiyono stated research and development is the research method used to validate, develop, and create the particular product as well as to test the effectiveness of the product [6]. The steps of 
Research and Development referring to Sugiyono (2015) are: (1) potential and problem, (2) data collecting, (3) product design, (4) design validation, (5) design revision, (6) product testing, (7) product revision, (8) product trial, (9) product revision, (10) mass production [4]. Nevertheless, because of the pandemic and the restriction that I face, I took only 6 of the 10 steps stated by Sugiyono, i.e., from step 1 (potential and problem) to step 6 (small-group product testing). That, however, will not have a significant impact on the study that I will conduct as the aims of the study are the ones included in the problem statement, i.e., to develop the design, to assess the feasibility of media, as well as to test its effectiveness on the small group [6].

The study is conducted to develop the comic strip as a media product for the learning of "social, economic, cultural, and religious diversity" included in Social Science subject for grade IV students of SDN 1 Munggu. The development of the comic strip is to improve the students' comprehension and learning outcomes.

The feasibility of the developed comic strip, subsequently, is assessed by the media validator and lesson materials specialist. Referring to the study conducted by Rabita (2015) media validation conducted by media specialists aims to find the feasibility of the developed media [7]. While the media validation conducted by the lesson materials specialist aims to assess the validity of the information included in the developed media. The assessment was conducted by the media specialist and lesson materials specialist by scoring the questions in the distributed questionnaire. The feasibility questionnaire distributed to the lesson materials and media specialists used the descriptive assessment with percentage using likert scale. Data collected from the fulfilled feasibility questionnaire subsequently were converted into qualitative data using 5 points likert scale referring to Purwanto's conversion formula [8].

Similar to the study conducted by Mardianti (2018) showed that the comic strip as learning media validated and revised as suggested by the validators are feasible for the field testing [9]. Data collected in the study were media assessment by the validators, questionnaire of teacher's, students', and students' parents' responses.

I used Sugiyono's development model as the research design. I choose this model because it fits the research and development I conducted that tends to analyze the needs and to test the effectiveness of the product to function well for the advancement of education. I conduct research and development that creates comic strips containing social science lesson material for grade IV students of SDN 1 Munggu.

\section{RESULT AND DISCUSSION}

This study develops the comic strips as media learning for social, economic, cultural, ethnical, and religious diversity in Indonesia lesson of Social Science subject for grade IV students. It was stated in the study conducted by Roslina (2017) The researcher aims that the use of pictures as a visual medium in the teaching-learning process is intended to make teaching-learning more effective and efficient [10]. If teaching-learning runs effectively and efficiently, then it means the quality of learning outcomes can be improved. It means that the usage of the comic strip as the media in the learning and teaching process is intended to create more effective and more efficient learning. If the learning runs effectively and efficiently, then the quality of the learning outcome can be improved.

It was similar to the study conducted by Asrifan (2015) that states that In research, it finds that teaching by using pictures story can improve the students' writing skill. The students, who are taught by using comic strips, have better performance in writing than the students who are taught conventionally [11]. It means that comic strips can improve the students' writing skills if compared to the conventional method.

The discussion of the analysis of the research that I founded on social science learning mainly social, economic, cultural, ethnical, and religious diversity in Indonesia for grade IV students of SDN 1 Munggu comprises (1) development of comic strip design; (2) feasibility of the comic strip; (3) the effectiveness of the comic strip.

\section{A. Development of Comic Strip}

The product that I develop is a comic strip containing the lesson of social, economic, cultural, ethnic, and religious diversity in Indonesia learned in social science subjects for grade IV students. The study conducted by Sukanda (2016) shows that comic strip is the media that demonstrate the daily example into the pictures added with the example stories added with explanations and illustration/pictures [12]. Ngurdiyantoro (2010) states that the comic strip containing the good words in the narration and the dialog is placed under the picture panels [13].

The product design that I develop consists of: (1) cover of the comic strip, (2) one-page containing basic competencies, indicators, and the learning objectives; (3) table of contents; (4) the instructions of how to use the comic strip; (5) concept map; (6) content of comic strip; (7) author page. The developed comic strip is subsequently printed on the A5 ivory paper in order not to be delicate and to be portable. I used the character of Adit and Bang Jarwo. I am inspired to use those characters created by Eki N.F, Deddy Otara, and Zulfa because they are popular cartoon characters so they will attract the students more easily.

The design of the comic strip containing one of the lessons in a social science subject, i.e. social, economic, cultural, ethnical, and religious diversity in Indonesia was developed in line with the fulfilled questionnaire of the teacher's and the students' needs. I made a revision of the comic strip adjusted to the assessment made and the advice given by the lesson materials and the media specialists. Regarding the feasibility of the comic strip, according to the specialists, the product is affirmed as "highly feasible" to be used as the learning media for the learning of social, economic, cultural, ethnical, and religious diversity in Indonesia in the Social Science subject. 


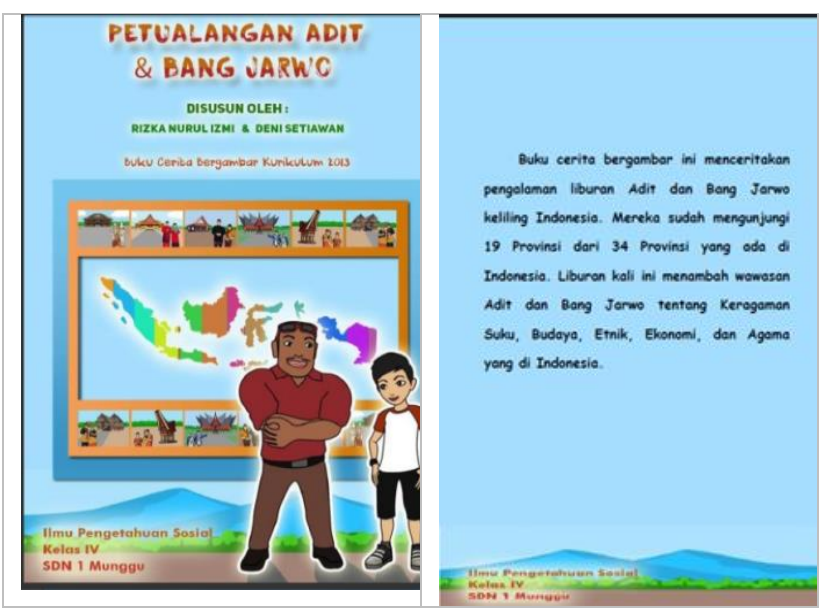

Fig. 1. Front and Back Cover

Small group product testing that involved 12 students was conducted to evaluate the feasibility and the effectiveness of the comic strip. The comic strip feasibility was analyzed through the fulfilled questionnaire containing the students', the teacher's, and the students' parents' responses. While the effectiveness of the media was analyzed through pretest and posttest.

\section{B. Media Feasibility}

The assessment of the comic strip was conducted using the assessment instruments suggested by the media specialist, the lecturer in the Department of Curriculum and Education Technology, Faculty of Education, UNNES and lesson materials specialist, the lecturer in the Department of History, Faculty of Social Science, UNNES. The assessment of the two specialists is presented in Table I below.

TABLE I. MEDIA AND LESSON MATERIALS VALIDATION ASSESSMENT

\begin{tabular}{llll}
\hline No & \multicolumn{1}{c}{ Assessment } & Percentage & Criteria \\
\hline 1 & Media Validation & $85,3 \%$ & Highly feasible \\
2 & Lesson Materials & $97,5 \%$ & Highly feasible \\
& Validation & & \\
\hline
\end{tabular}

Based on Table I assessment validation conducted by media specialists got a percentage point of $85.3 \%$, included in the excellent category, and the assessment of lesson materials specialists got a percentage point of $97.5 \%$, included in the excellent category. The media and lesson materials specialists gave advice and suggestions for the comic strips. I have revised as advised and suggested by them, but still maintain the initial design of the comic strips I have made, as well as adjusted it to teacher's and students' needs.

The feasibility of the comic strip entirely can be viewed on the questionnaire of the teacher's, the student's, and the student's parents' responses. Based on the questionnaire, it is shown that they give positive responses to the comic strip product containing social, economic, cultural, ethnical, and religious diversity in Indonesia lesson in Social Science subject, the percentage of the response is $100 \%$ which means highly feasible.

\section{Media Effectiveness}

The effectiveness of the comic strip can be viewed from the students' learning outcome. The learning outcome consists of pretest and posttest scores assessed using normality test, t-test, and N-Gain test.

TABLE II. RESUlt OF SMALl GROUP NORMALITY TEST

\begin{tabular}{llllll}
\hline Data & Mean & $\begin{array}{l}\text { Standard } \\
\text { of } \\
\text { deviation }\end{array}$ & Lo & $\begin{array}{l}\text { L } \\
\text { tabel }\end{array}$ & Remarks \\
\hline Pretest & 54.6667 & 16,999 & 0.229 & 0.242 & $\begin{array}{l}\text { Distributed } \\
\text { normally } \\
\text { Pistributed } \\
\text { normally }\end{array}$ \\
\hline
\end{tabular}

From Table II, I gained the calculation of normality test on the small group L0 pretest $=0.229$ and L0 posttest $=$ 0.083 . Based on the data, it can be concluded that small group testing of pretest and posttest are normally distributed because L $0<$ Ltable.

TABLE III. ANALYSIS TEST OF SMALL GROUP T-TEST

\begin{tabular}{lllllll}
\hline $\begin{array}{l}\text { Classroo } \\
\text { m }\end{array}$ & N & Mean & $\begin{array}{l}\text { Varian } \\
\text { s }\end{array}$ & $\begin{array}{l}\text { Tcoun } \\
\text { t }\end{array}$ & $\begin{array}{l}\text { ttabl } \\
\mathbf{e}\end{array}$ & $\begin{array}{l}\text { Criteri } \\
\mathbf{a}\end{array}$ \\
\hline Pretest & 1 & 54.666 & 103,05 & & & \\
& 2 & 7 & & 5461,3 & $-3,46$ & $\begin{array}{l}\mathrm{H} 0 \quad \text { is } \\
\text { rejected }\end{array}$ \\
Posttest & 1 & 76 & 128,95 & 3 & & \\
\hline
\end{tabular}

Based on Table III by calculating the small group t-test using paired sample t-test paired observation I got t_count $=$ $-3,46$ and ttable with $\alpha=5 \%$ is 1.78 resulted in $\leq-$ ttable $=$ $3.46 \leq-1.78$ therefore $\mathrm{H} 0$ is rejected and $\mu \mathrm{B}<0$. The result shows that at the step of small group product testing, the students' Social Science learning outcome particularly social, economic, cultural, ethnic, and religious diversity in Indonesia changes.

TABLE IV. N-GAIN TEST

\begin{tabular}{cclcl}
\hline \multirow{2}{*}{ Classroom } & \multicolumn{2}{c}{ Mean Score } & \multirow{2}{*}{ N-gain } & \multirow{2}{*}{ Criteria } \\
\cline { 2 - 4 } & Pretest & Posttest & & \\
\hline Small group & 54,666667 & 76 & 0,470588235 & Fair \\
\hline
\end{tabular}

Based on the data processing using the N-gain test on the small group product testing, the result is that by applying the comic strip to 12 grade IV students of SDN 1 Munggu, their learning outcome improved to 0.470588235 that meets the fair category. The difference between means of pretest and posttest is 21.3333. The improvement of the students' learning outcome on Social Science subject particularly the lesson of social, economic, cultural, ethnic, and religious diversity in Indonesia shows that the comic strip can effectively improve the learning outcome of the students in SDN 1 Munggu.

That result is supported by the study conducted by Suryaningsih (2017) that shows that comic strips are 
feasibly used as a learning media/teaching tool [14]. Faroh \& Setiawan (2018) stated montage-based comic strip is feasible and effective to be applied to Social Science learning [15].

The theoretical implications in this study are related to the theories used by researchers to develop illustrated story media. The development of picture story media can improve students' social studies results on social, economic, cultural, ethnic, and religious diversity materials in Indonesia. it supports previous research that illustrated story media can improve student learning outcomes. There is an increase in social studies results of social, economic, cultural, ethnic, and religious diversity materials in Indonesia between learning without the use of pictorial story media and learning using picture story media.

The development of illustrated story media has practical implications related to the results of research on the implementation of the expected learning process. For students, social science learning materials of social, economic, cultural, ethnic, and religious diversity in Indonesia using picture story media can improve student learning outcomes and understanding. This is evidenced by the increasing results of students' social studies after the media implemented illustrated stories in the learning process. For teachers, learning using picture story media can be a choice of learning media to improve student learning outcomes, teachers become motivated in the learning process. For schools, the application of picture story media that can improve student learning outcomes can be used as a way to improve the quality of the school by using learning media by another teacher.

\section{CONCLUSION}

The comic strip containing the lesson of social, economic, cultural, ethnic, and religious diversity in Indonesia in the study used the Research and Development method according to Sugiyono [4]. The feasibility of the comic strip containing the lesson of social, economic, cultural, ethnic, and religious diversity in Indonesia learned in Social Science subject for grade IV students in SDN 1 Munggu was validated by the media and lesson materials specialists. The feasibility of the lesson materials was validated at a percentage point of $97.5 \%$ (meeting the criteria of highly feasible category) and the media feasibility got a score of $85.3 \%$ (highly feasible). Small group t-test resulted in $\mathrm{t} \leq$-ttable or $-3.463 \leq-1.78$, so $\mathrm{H} 0$ is rejected and $\mu \mathrm{B}<0$. That showed that after conducting small group product testing, the student's learning outcome on the lesson of social, economic, cultural, ethnic, and religious diversity in Indonesia learned in Social Science subject changed after using the comic strip as the teaching tool. Meanwhile, the calculation of small group $\mathrm{N}$-gain is 0.470588235 which is included in the fair category. This shows that on the small group testing, the comic strip can effectively improve the students' learning outcome. We can conclude that the use of comic strips on the lesson of social, economic, cultural, ethnic, and religious diversity in Indonesia learned in Social Science subject for grade IV students can effectively improve the students' learning outcome.

\section{ACKNOWLEDGMENT}

The researchers expressed their gratitude to the principals of SDN 1 Munggu, the teachers at SDN 1 Munggu, the bestari partners who have provided guidance and encouragement so that they can complete this research well. Hopefully, the results of this research can be used for the development and improvement of social science content learning in elementary schools.

\section{REFERENCES}

[1] A. Susanto, Teori Belajar dan Pembelajaran di Sekolah Dasar, Jakarta: Prenadamedia Grup, 2013.

[2] A. R. Adzka, "Pengembangan Buku Cerita Negara "Ayo Menanam Sayuran" Pada Anak Tuna Grahita Kelas VI SLBN Cerme," Jurnal Seni Rupa, vol. 07, no. 03, pp. 81-87, 2019.

[3] A. S. d. A. P. Nunuk Suryani, Media Pembelajaran Inovatif dan Pengembangannya, Bandung: PT Remaja Rosdakarya Offset, 2018.

[4] L. Masruro, "Penggunaan Media Cerita Bergambar Terhadap Hasil Belajar Siswa Pada Materi IPS Kelas III SD YPI Darussalam Cerme-Gresik," JPGSD, vol. 06, no. 02, p. 201, 2018.

[5] E. N. F. R. E. Arash Hashemifardnia, "The Effect of Teaching Picture-books on Iranian Elementary EFL Learners' Vocabulary Learning," JELTL, vol. 3, no. 3, p. 248, 2018.

[6] Sugiyono, Metode Penelitian Pendidikan, Bandung: Alfabeta, 2015.

[7] R. P. Rabita, "Pengembangan Media Pembelajaran Buku Cerita Bergambar Untuk Pembelajaran IPS Siswa SMP Kelas VII," Jurnal Kreatif, vol. 6, 2015

[8] Purwanto, Evaluasi Hasil Belajar, Yogyakarta: Pustaka Pelajar, 2013.

[9] D. Mardanti, "PengembaBuku Cerita Bergambar Berbasis Dilema Moral Sebagai Media Pendidikan Moral Untuk Anak Kelas Tinggi di SD Budi Mulia Dua Sedayu, Bantul," E-Jurnal Prodi Teknologi Pendidikan, vol. 7, no. 8, pp. 745-749, 2018.

[10] Roslina, "The Effect Of Picture Story Books On Students' Reading Comprehension," ALLS, vol. 8, no. 2, p. 215, 2015.

[11] A. Asrifan, "The Use of Pictures Story in Improving Students' Ability to Write Narrative Composition," International Journal Of Language And Linguistics, vol. 3, no. 4, p. 246, 2015.

[12] F. Sukanda, "Pengembangan Media Buku Cerita Bergambar Tema Pekerjaan untuk Meningkatkan Pengetahuan Karier Siswa Kelas IV Sekolah Dasar," Jurnal Mahasiswa Bimbingan Konseling, vol. 6, no. 2, 2016.

[13] B. Ngurdiyantoro, Sastra Anak, Yogyakarta: Gadjah Mada University Press, 2013.

[14] L. F. Eni Suryaningsih, "Pengembangan Buku Cerita Bergambar Tentang Mitigasi Bencana Erupsi Gunung Api Untuk Siswa SD," Profesi Pendidikan Dasar, vol. 4, no. 2, p. 116, 2017.

[15] D. S. Nisrina Nurul Faroh, "Pengembangan Buku Cerita Bergambar Berbasis Montase Pembelajaran IPS Kelas V," $J L J$, vol. 7, no. 4, p. 37, 2018. 